\title{
Influence of Service Quality on Banking Customers' Behavioural Intentions
}

\author{
Dr. K. Ravichandran \\ Assistant Professor, School of Management, New York Institute of Technology \\ Abudhabi, United Arab emirates. \\ E-mail: varshal2@yahoo.com \\ Ms. K.Bhargavi \\ Research Scholar, Department of Commerce, Urumu Dhanalakshmi College \\ Trichy, Tamil Nadu, India \\ E-mail: bhargavirajak@gmail.com.
}

Mr. S. Arun Kumar

Department of Management Studies

Saranathan College of Engineering, Trichy, Tamilnadu, India

E-mail: arunkanthh@yahoo.co.in

\begin{abstract}
Investigating the influence of service quality variables on multidimensional model of customers' behavioral intentions should help to measure, control and improve customer perception of service quality by public banks. Hence, this relational impact should be a central concern for public retail bank managers as well as for service management academics and practitioners. Purposive sampling technique is used to select the respondents from two major public banks of Tirchirappalli city of Tamilnadu, India. Univariate analysis is used to analyze the demographic and rational variables. The service quality variables of tangibility, responsiveness and empathy dimensions play an important role in predicting Customer behavioral intention which is identified using multiple regression analysis.
\end{abstract}

Keywords: SERVQUAL, Behavioral Intention, Loyalty and Perception of Service Quality, Rational, Tangibility, Responsiveness, Empathy

\section{Introduction:}

The Indian banking industry is going through turbulent times. With the lowering of entry barriers and blurring product lines of banks and non-banks since the financial sector reforms, banks are functioning increasingly under competitive pressures emanating from within the banking system, from non-banking institutions and from the domestic and international capital markets. In this era of mature and intense competitive pressures, it is imperative those banks maintain a loyal customer base. In order to achieve this and improve their market and profit positions, many retail banks are directing their strategies towards increasing customer satisfaction and loyalty through improved service quality. In the present competitive Indian banking context, characterized by rapid change and increasingly sophisticated customers, it has become very important that banks in India determine the service quality factors which are pertinent to the customers' selection process. With the advent of international banking, the trend towards larger bank holding companies and innovations in the marketplace, the customers have greater and greater difficulty in selecting one institution from another. Therefore the current problem for the banking industry in India is to determine the dimensionality of customer perception of service quality. This is because if service quality dimensions can be identified, service managers should be able to improve the delivery of customer perception of quality during the service process and have greater control over the overall outcome. Moreover, investigating the influence of the dimensions of service quality on customers' behavioral intentions should provide a better understanding of the drivers of customer satisfaction and also help to specify measure, control and improve customer perception of service quality. Hence, to gain and sustain competitive advantages in the fast changing public retail banking industry in India, it is crucial for banks to understand in-depth what customers perceive to be the key dimensions of service quality and what impacts the identified dimensions have on customers' behavioral intentions? The issue of customer retention is an important one for service organizations. Ndubisi (2003) has related superior service with customer perceived mutualism (in customer-firm interaction) which is associated with 
customer support, which outcomes are increasing market share and/or profits. The study also related poor service with customer perceived commensalism and parasitism which lead customer resistance and in turn erosion of profits and/or market share. It has also been suggested that service quality has a direct effect on organizations' profits, since it is positively associated with customer retention and customer loyalty (Baker \& Crompton, 2000; Zeithaml \& Bitner, 2000).

Studies have shown that it costs six times more to attract new customers than to retain the existing ones (Rosenberg \& Czepiel, 1983). Reports have also shown that the net increase of the present value of profits that results from 5 percent increase in customer retention varies between 25 percent and 95 percent over different industries (Oliver, 1999), Ndubisi (2003) and Zeithaml et al., (1996).

Ndubisi suggested that customers perceive their relationship with the firm in three different lights (i.e. mutualism, commensalism, and parasitism) depending on whether (in the customer's eyes) value was created and delivered or not, and these perceptions will predict the kind of response (either support or resistance) customers give to services providers each having different implications on the firm's profits and/or market share.

Zeithaml et al. used SERVQUAL (Service Quality) model and proposed that perceived service quality was related with positive behavioral intentions, which could be viewed as signals of retention or defection. According to the latter model, behavioral intentions are a multi-dimensional concept, consisting of word-of-mouth (WOM), purchase intentions, price sensitivity, and complaining behavior. Fishbein and Ajzen (1975) suggested that behavioral intentions when properly measured could to a large degree predict actual behavior. Since then, number of research has used intention to predict behavior (e.g. Davis 1989; Davis et al., 1989; Mathieson 1991; Taylor \& Todd 1995; Venkatesh (2000), while others have seriously questioned intention as a predictor of actual behaviour (Straub etal. 1995; Bentler \& Speckart 1979; Songer-Nocks 1976). Nonetheless, Baker and Crompton (2000);Bloemer et al., (1999) applied Zeithaml et al.'s (1996) model and found evidence for its usefulness in predicting elements of customer loyalty. All three studies indicated a need for further research on the relationship between service quality and Customer behavioral intentions in a variety of service sectors.

In view of the practical value of research on customer retention, combined with the limited published research on Indian banking services, the current work aims to evaluate the degree to which service quality dimensions can predict the multi-dimensional model of behavioral intentions, as suggested by Zeithaml et al. (1996) among public banking customers in India.

\subsection{Research Objective}

To understand the Socio-demographic and Rational profile of public retail banking consumers.

Aims to evaluate the degree to which service quality dimensions can predict the multi-dimensional model of behavioral intentions as suggested by Parasuraman et al. (1996) among public banking customers in India.

To identify the important underlying perception of service quality dimensions among public retail banking consumers.

\section{Review of Literature}

Service quality: Perceived service quality has been defined as a global judgment or attitude relating to the superiority of a service (Zeithaml and Bitner, 2000). The majority of research on service quality has been built around the SERVQUAL (Parasuraman et al., 1988) methodology. The SERVQUAL model suggests that service quality can be measured by identifying the gaps between customers' expectation and perceptions of the performance of the service. Parasuraman et al. (1988) also suggested that service quality was a many-sided concept consisting of five dimensions: reliability, assurance, tangible, empathy, and responsiveness. Reliability refers to the ability to perform the promised service dependably and accurately; assurance refers to the knowledge and courtesy of employees and their ability to convey trust and confidence; tangible refers to the appearance of the physical facilities, equipment, personnel and communication materials; empathy refers to the provision of caring, individualized attention to customers; and responsiveness refers to the willingness to help customers and to provide prompt services. The SERVQUAL instrument has been widely used in the marketing literature in a variety of sectors, including leisure related organizations, such as hotels (Ingram and Daskalakis, 1999; Oh, 1999), travel agencies (Luk, 1997), parks and recreation (McKay and Crompton 1990), tourism attractions / resorts (Bigne et al. 2001), and leisure/sport centers (Howatet al., 1999; Lentell, 2000). The value of the SERVQUAL instrument as an assessment and management tool has been well documented. However, the model has also been criticized on a theoretical and operational level (Buttle, 1995). On the theoretical level it has been criticized as being based on the disconfirmation paradigm, which has been widely adopted in the satisfaction literature (Oliver, 1996) rather than on the attitudinal one. Furthermore, researchers (e.g. Cronin and Taylor, 1992; Teas, 1993) have questioned the validity and reliability 
of the gap model, suggesting that measuring perceptions alone might provide a better indication of service quality than measuring the difference between expectations and perceptions. Finally, some researchers have suggested that the service quality dimensions are contextual and not universally applicable (Ekinci and Riley, 1999; Williams, 1998). The operational criticism has focused on the difficulties in conceptualizing expectations, the limited number of items within each dimension, the problems related to the double administration of the instrument (customer confusion and boredom), and the limited proportion of variance extracted by the five factors (Buttle, 1995). The issue of service quality dimensions being contextual is an important impetus for adapting and replicating the instrument across several services and offers some future research directions such as testing the model in different environment, services sector, and scenario.

2.1 Behavioral Intentions: According to Zeithaml et al.'s (1996) model, the behavioral consequences of service quality mediate between service quality and the financial gains or losses from the retention or defection. When customers' perceptions of service quality are high, the behavioral intentions are favorable, which strengthens their relationship with the organization. In the other hand, when service quality assessments are low, customers' behavioral intentions are unfavorable and the corresponding relationship with the company deteriorates. Zeithaml et al. (1996) also suggested that behavioral intentions were indicators, which showed whether customers had remained with or had defected from the organization. The conceptualization of behavioral intention is an important part of the model. Zeithaml et al. (1996) suggested that favorable behavioral intentions included elements such as saying positive things and recommending the services to others, paying the price premium to the company and expressing cognitive Loyalty to the organization. Cognitive loyalty has been operationalized as the service that first comes to one's mind when making a purchase decision and the service, which was a customers' first choice among alternatives (Bloemer et al., 1999; Pritchard et al., 1992).

The relationship between service quality dimensions and the multi-dimensional model of behavioral intention has not been adequately investigated in the service quality literature (Baker and Crompton, 2000; Bloemer et al., 1999). Boulding et al. (1993) reported that the overall service quality perception were positively related with willingness to recommend and negatively related with switching and complaining behavior (Kelley et al., 1993). Contradictory results were reported in terms of the relationship between the overall service quality and behavioral intention. Cronin and Taylor (1992) reported non-significant relationship, while Boulding et al. (1993) reported significant and positive ones. Finally, Zeithaml etal. (1996) reported positive relationship between overall service quality and price sensitivity. Research on the relationship between service quality dimension and the multi-dimension model of behavioral intentions as proposed by Zeithaml et al. (1996) is still limited. In a recent study, Bloemer et al. (1999) applied the model and provided evidence that the patterns of relationships were not universal but they were industry-based. For example, in the entertainment industry, WOM was positively affected by responsiveness and tangibles, while in the food service industry it was positively affected by assurance and empathy. Furthermore, behavioral intentions were determined by reliability in the entertainment industry and by assurance and empathy in the food industry. The study by Baker and Crompton (2000) also supported the model. The authors investigated customers' perception in the tourism industry (tourist events). They expanded the model by including the concept of customer satisfaction into the framework. Using structural modeling design, they provided evidence that service quality dimensions (adjusted to the context of tourism events) were directly and positively related with purchase intentions, customer loyalty and willingness to pay more money.

\subsection{Components of Behavioral-Intentions Battery}

On the basis of analysis across four contrasting industries, computer manufacturer, retail chain, automobile insurer and life insurance, Zeithaml, Berry and Parasuraman (1996) proposed a comprehensive, multi-dimensional framework of customer behavioral intentions for use within a service industry. The framework incorporates 13-items across five-dimensions: loyalty to company (loyalty) propensity to switch (switch), willingness to pay more (pay more), external responses to a problem (external responses) and internal responses to a problem (internal responses).

Bloemer, de Ruyter and Wetzels (1999) raised a number of conceptual and empirical criticisms of the Behavioral-Intentions Battery. Their conceptual criticism focused on inter-dimensional overlap (e.g., various expressions of customer complaining behavior or response to a dissatisfactory service encounter are distributed over two factors, "external response to a problem" and "internal response to a problem"; pricing-related loyalty intentions are placed under two factors, "propensity to switch" and "willingness to pay more). Empirically, they claimed that the use of a single-item measure, "internal response to a problem", should be avoided. Furthermore, they argued that the five-factor solution did not appear to provide an unambiguous and consistent factor pattern and that this impacts the reliability of the measure. On the basis of analysis across four service industries: entertainment, fast food, supermarkets and health care, they concluded that service loyalty is a multi-dimensional construct consisting of the 
following four dimensions: Word-of-mouth, Purchase intentions, Price sensitivity, and Complaining behavior. As suggested by Bloemer, de Ruyter and Wetzels (1999), in order to achieve better reliability measure, the original five dimensions battery of 13 items construct got modified into four dimensions by adding the last $13^{\text {th }}$ single item from the fifth dimension along with the fourth dimension items of Parasuramans' Multidimensional behavioral intention Model. Hence, the research Model for this study is as depicted in the Figure 1.

\section{Figure1: Proposed Research Model for this study}

\subsection{Methodology}

The study empirically investigates the relationship between service quality dimensions and behavioral intentions from the viewpoint of consumers of banking services in Tiruchirappalli City of Tamilnadu India. Zeithaml et al.'s (1996) theoretical framework of behavioral intentions was used in the measurement of Behavioral intentions and the five dimensions of SERVQUAL (Parasuraman et al., 1988) were used in the measurement of perception of service quality.

A total of 102 usable responses were collected from customers of two public banks located in Tiruchirappalli (bank A-with the widest customer base and largest number of branches, and bank B-with the narrowest customer base and least number of branches) and analysis was done. Customers were approached to complete the questionnaire were Purposive sampling of Non-Probability sampling were used for the study. Although the sample size is relatively small for a consumer research, nonetheless the objective of the current study is to test the 22 items of SERVQUAL construct and its relationship with Zeithaml et al.'s (1996) Multidimensional model of behavioral intentions (13 items battery) was achieved. Customer perceptions of service quality were measured using 22 items taken from SERVQUAL (Parasuraman et al., 1988). They include the following dimensions: (1) Tangibles (2) Reliability (3) Responsiveness (4) Assurance and (5) Empathy. A Five point Likert-type scale, ranking from (1) strongly disagree to (5) strongly agree was used for both the behavioral intentions and the service quality scales.

\section{Emprical Findings:}

As the data indicate in the above table that the large group of respondents belong to age group below 25(32.4\%),26-35(30.4\%),36-45(20.6\%)and above 46(16.5\%),gender proportion with male(80.4\%) and female(19.6\%),educational qualification majority with PG qualification (42.4\%) and followed by(25.5\%) of UG qualification, marital status with married(54.9\%) and unmarried (45.1\%),occupation of respondents with government(28.4\%),private(26.5\%) and self employed(20.6\%),Number of dependents-four dependents(52\%) followed by three dependents (35\%), Type of Account- saving account (80.4\%),followed by current account (11.7\%), Frequency of visit , 1-2times per monthly(41.2\%) followed by 1-2 times per fortnightly (31.4\%).

\section{Insert Table 1 Here}

\section{Insert Table 2 Here}

The alpha values were calculated to assess the internal consistency reliabilities of the SERVQUAL scales. For SERVQUAL scales, the value of .843 indicated adequate reliability (Nunnally, 1978).

\section{Insert Table 3 Here}

The alpha values were calculated to assess the internal consistency reliabilities of the BI scales. For behavioral intentions scales, the value of .706 indicated adequate reliability (Nunnally, 1978).

\subsection{Regression Analysis:}

The service quality variables are regressed with the different dimensions of Behavioral Intention Battery to analyze their contribution using Stepwise Method in Multiple regression analysis, which are as follows

\section{Insert Table 4 Here}

The above equation shows the impact of the variables of service quality aspects such as convenient operating hours-empathy ,modern looking equipments-Tangibility, delivering error free records-Reliability, providing prompt service -Responsiveness, Visually appealing materials-Tangibility ,Employees giving personal attention to customers-Empathy, Performing service right at the first time-Reliability, employees knowledge -Assurance ,bank telling customers when exactly service will be performed -Responsiveness on the Attitudinal Loyalty of retail public banks. On an average if the convenient operating hour service change by 1 unit, there will be 0.359 units increase in the Attitudinal Loyalty when other variables are kept constant. Moreover the result of the t-test confirms that the calculated partial regression coefficient such as (0.359), (.324), (-.206), (.205) and (.251) are highly significant at 1 percent level and 5 percent level. Similarly the multiple R of 0.687 shows there exist a relationship of 68.7 percent between variables of service quality aspects and attitudinal loyalty. The R Square value of 0.472 
describe that the variables of service quality explained a variation of 47.2 percent in the attitudinal loyalty. Finally, the result of F-test signifies that the explained variation by the above said variables in the SERVQUAL was highly significant at one percent level.

From the above analysis it is concluded that the variables of service quality namely convenient operating hours of bank, modern looking equipments, delivering error free records and employees giving personal attention were the dominant variables that increase the attitudinal loyalty among customers of public retail banks.

\section{Insert Table 5 Here}

The above equation shows the impact of the variables of service quality aspects such as bank provides the service at the time it promise to do so-Reliability and bank physical facilities are visually appealing with modern looking building and amenities on the switching propensity of retail public banks. On an average if the bank provides the service at the time it promise to do so change by 1 unit, there will be 0.313 units increase in the switching propensity when other variables are kept constant. Moreover the result of the t-test confirms that the calculated partial regression coefficient such as (0.313) and (.309) are highly significant at 1 percent level and 5 percent level. Similarly the multiple $\mathrm{R}$ of 0.386 shows there exist a relationship of 38.6 percent between variables of service quality aspects and switching propensity. The R Square value of 0.149 , exhibits that the variables of service quality explained a variation of 14.9 percent in switching propensity. Finally, the result of F-test signifies that the explained variation by the above said variables in the SERVQUAL was highly significant at one percent level.

From the above analysis it is concluded that the variables of service quality namely bank provides the service at the time it promise to do so and bank's physical facilities are visually appealing with modern looking building and amenities were the dominant variables that increase the switching propensity among customers of public retail banks.

\section{Insert Table 6 Here}

The above equation shows the impact of the variables of service quality aspects such as bank's physical facilities are visually appealing with modern looking building and amenities -Tangibility ,convenient operating hours-empathy, employees telling customers when exactly service will be performed -Responsiveness and employees knowledge -Assurance on the Pay more sum intention of retail public banks. On an average if the modern looking buildings and amenities change by 1 unit, there will be 0.443 units increase in the pay more sum intention when other variables are kept constant. Moreover the result of the t-test confirms that the calculated partial regression coefficient such as (0.443), (.362), (-.338) and (.313) are highly significant at 1 percent level and 5 percent level. Similarly the multiple R of 0.593 shows there exist a relationship of 59.3 percent between variables of service quality aspects and pay more sum intention. The R Square value of 0.351 , exhibits that the variables of service quality explained a variation of 35.1 percent in attitudinal loyalty. Finally, the result of F-test signifies that the explained variation by the above said variables in the SERVQUAL was highly significant at one percent level.

From the above analysis it is concluded that the variables of service quality namely bank's physical facilities are visually appealing with modern looking building /amenities and Employees tell customers exactly when the service will be performed were the dominant variables that increase the Pay more sum intention among customers of public retail banks.

\section{Insert Table 7 Here}

The above equation shows the impact of the variables of service quality aspects such as modern looking equipments, employees understand the specific needs of the customers - Empathy, promises to do something - Reliability, employees give personal attention to customers - empathy, employees behavior insist confidence to customers assurance, Frontline employees are neatly appearing - Tangibility on the switching propensity of retail public banks. On an average if the modern looking equipments change by 1 unit, there will be 1.512 units increase in the External and internal response when other variables are kept constant. Moreover the result of the t-test confirms that the calculated partial regression coefficient such as (1.512), (1.008), (.764), (-.784), (508) and (.442) are highly significant at 1 percent level and 5 percent level. Similarly the multiple R of 0.609 shows there exist a relationship of 60.9 percent between variables of service quality aspects and External and Internal response. The R Square value of 0.371 , exhibits that the variables of service quality explained a variation of 37.1 percent in external and internal response. Finally, the result of F-test signifies that the explained variation by the above said variables in the SERVQUAL was highly significant at one percent level.

From the above analysis it is concluded that the variables of service quality namely Modern looking equipments and employees understands customers specific needs were the dominant variables that increase the external and internal response intention among customers of public retail banks. 


\section{Insert Table 8 Here}

The above equation shows the impact of the variables of service quality aspects such as convenient operating hours, Modern looking equipments, bank understand the specific needs of customer, banks frontline employees are neat appearing. On an average if the modern looking buildings and amenities change by 1 unit, there will be 0.135 units increase in the overall behavioral intention when other variables are kept constant. Moreover the result of the t-test confirms that the calculated partial regression coefficient such as (0.135), (.288), (.170), (.147) and (.100) are highly significant at 1 percent level and 5 percent level. Similarly the multiple R of 0.665 shows there exist a relationship of 66.5 percent between variables of service quality aspects and overall behavioral Intention. The R Square value of 0.443 , exhibits that the variables of service quality explained a variation of 44.3 percent in overall behavioral intention. Finally, the result of F-test signifies that the explained variation by the above said variables in the SERVQUAL was highly significant at one percent level.

From the above analysis it is concluded that the variables of service quality namely Modern looking equipments and employees understands customers specific needs were the dominant variables that increase the overall behavior intention among customers of public retail banks.

\section{Conclusion}

It is evaluated that there is a degree of prediction of service quality on the multidimensional model of behavioral intentions developed by Parasuraman, etal, 1996 .Through multiple regression analysis; the impact of service quality variables on each dimension of behavioral intentions is analyzed. Attitudinal loyalty is well predicted by service quality variables like convenient operating hours of bank, modern looking equipments, delivering error free records and employees giving personal attention were the dominant variables that increase the attitudinal loyalty among customers of public retail banks. In Switching propensity dimension ,bank provides the service at the time it promise to do so and bank's physical facilities are visually appealing with modern looking building \& amenities were the dominant variables of service quality that increase the switching propensity among customers of public retail banks. In Pay More Sum dimension, service quality variables such as bank's physical facilities are visually appealing with modern looking building /amenities and Employees tell customers exactly when the service will be performed were the dominant variables that increase the Pay more sum intention among customers of public retail banks .In External and Internal response dimension, the variables of service quality namely Modern looking equipments and employees understands customers specific needs were the dominant variables that increase the external and internal response intentions among customers of public retail banks. To highlight the conclusion in a nutshell, the service quality variables of tangibility, responsiveness and empathy dimensions play important role in predicting Customer behavioral intention .Hence, these issues should be a central concern for public retail bank managers as well as service management academics and practitioners. Bank managers are suggested to focus on these specific dominant SERVQUAL variables on customers' behavioral intentions to measure, control and improve customer perception of service quality among Indian public retail banking customers. Additionally, the results of factor analysis showed evidence that the proposed model of SERVQUAL construct (Parasuraman, etal, 1988) does not factor loaded as proposed originally by them as per this study and analysis, since the Indian retail banking customers' cultural setup, demographic setup as observed in the study and their respective service quality preference varies. To gain and sustain competitive advantages in the fast changing banking industry in India, it is crucial for banks to understand in-depth, what customers perceive to be the key dimensions of service quality.

Since the results of this study are based on consumers' perceptions only, future research should investigate the congruence between consumers' and service providers' perceptions. This will help the banking industry to better understand whether both consumers and banks have the same perceptions regarding issues relevant to retention. While this study found that service quality construct proposed by Parasuraman (1988) alone is not effective in predicting behavior intention, future research may attempt to explore the "unexplored" constructs that consumers would value most. For example, are consumers more concerned about the convenience issue such as location of branches, or the use of technology? Or are consumers more focused on how bank staff delivers services? Given the importance of employee competence, future research should also examine the impact of employees' behavior that could affect customer retention.

\section{References}

Ajzen, I. \& Fishbein, M. (1980). Understanding Attitudes and Predicting social Behavior. Englewood Cliffs, NJ:Prentice Hall.

Baker, D. \& Crompton, J. (2000). Quality, Satisfaction and Behavioral Intentions. Annals of Tourism Research. 27,785-804. 
Bentler, P.M. \& Speckart, G. (1979). Attitude Causes Behaviors: A Structured Equation Analysis. Journal of Personality and Social Psychology, 40, 226-238.

Bigne, E., Sanchez, I. \& Sanchez, J. (2001). Tourism Image, Evaluation Variables and After Purchase Behavior:Inter-relationship. Tourism Management, 22, 607-16.

Bloemer, J., de Ruyter, K. \& Wetzels, M. (1999). Linking Perceived Service Quality and Service Loyalty: A Multi-dimensional Perspective. Journal of Marketing, 33, 1082-1106.

Boulding, W., Kalra, A., Staelin, R. \& Zeithaml, V.A. (1993). A Dynamic Process Model of Service Quality: From Expectations to Behavioral Intentions. Journal of Marketing Research, 30, 7-27.

Buttle, F. (1995). SERVQUAL: Review, Critique, Research Agenda. European Journal of Marketing, 30, 8-32.

Cronin, J. \& Taylor, S. (1992). Measuring Service Quality: A Re-examination and Extension. Journal of Marketing, 56,55-68.

Davis F.D. (1989). Perceived Usefulness, Perceived Ease of Use, and User Acceptance of Information Technology. MIS Quarterly, 13, 3, 319-339.

Davis, F.D., Bagozzi, R. \& Warshaw, P.R. (1989). User Acceptance of Computer Technology: A comparison of two theoretical models. Management Science, 35, 8, 982-1003.

Ekinci, Y. \& Riley, M. (1999). Measuring Hotel Quality: Back to Basics. International Journal of Hospitality Management, 11, 287-93.

Fishbein, M. \& Ajzen, I. (1975). Belief, Attitude, Intentions and Behaviour: An Introduction to Theory and Research. Reading. MA: Addison-Wesley. Journal of Commercial Banking and Finance, Volume 3, Number 1, 2004.

Hofstede, G. (1980) Culture's Consequences. Thousand Oaks, CA: Sage.

Howat, G., Murray, D. \& Crilley, G. (1999). The Relationship between Service Problems and Perceptions of Service Quality, Satisfaction and Behavioural Intentions of Australian Public Sports and Leisure Center Customers. Journal of Park and Recreation Administration, 17, 42-64.

Ingram, H. \& Daskalakis, G. (1999). Measuring Quality Gaps in Hotels: The Case of Crete. International Journal of Contemporary Hospitality Management, 11, 24-30.

Kelley, S.W., Hoffman K.D. \& Davis, M.A. (1993). A Typology of Retail Failures and Recoveries. Journal of Retailing, 69, 429-52.

Lentell, R. (2000). Untangling the tangibles: Physical Evidence' and Customer Satisfaction in Local Authority Leisure Centers. Managing Leisure, 1-16.

Luk, S.T.K. (1997). An Examination of the Role of Marketing Culture in Service Quality. International Journal of Contemporary Hospitality Management, 9, 3-21.

MacKay, K. \& Crampton, J. (1990). Measuring the quality of recreation services. Journal of Park and Recreation Administration, 8, 47-56.

Mathieson, K. (1991). Predicting User Intentions: Comparing the Technology Acceptance Model with the Theory of Planned Behavior. Information Systems Research, 2,3, 173-191.

Murray, (1991). A Test for Services Marketing Theory: Consumer Information Acquisition Activities. Journal of Marketing, 55, 10-25.

Ndubisi, N.O. (2003). Service Quality: Understanding Customer Perception \& Reaction and Impact on Business. International Journal of Business, 5(2), 207-219.

Ndubisi, N.O. \& Igau, O.I. (2003). Can WOM Communication, Patronage Intention, and Complaining Behavior Predict Customer Retention and Loyalty. Labuan Bulletin of International Business and Finance, 1(1), 41-51.

Oh, H. (1999). Service Quality, Customer Satisfaction and Customer Value: A Holistic Perspective. Hospitality Management, 18, 67-82.

Oliver, R. (1996). Satisfaction: A Behavioral Perspective on the Consumer.

Oliver, R. (1999). Whence Consumer Loyalty? Journal of marketing, 63, 33-44.

Pritchard, M., Howard, D. \& Havitz, M. (1992). Loyalty Measurement: A Critical Examination and Theoretical Extension. Leisure Sciences, 14, 155-164. 
Parasuraman, A., Zeithaml, V. \& Berry, L. (1988). SERVQUAL: Multiple-item Scale for Measuring Consumer Perceptions of Service Quality. Journal of Retailing, 64, 12-40.

Robinson, J.P., Shaver, P.R. \& Wrights man, L.S. (1991). Criteria for Scale Selection and Evaluation, in Measures of Personality and Social Psychological Attitudes.San Diego, California: Academic Press.

Rosenberg, L. \& Czepiel, J. (1983). A Marketing Approach for Consumer Retention. Journal of Consumer Marketing, 1, 45-51.

Schiffman, L. \& Kanuk, L. (1999). Consumer Behavior. Journal of Commercial Banking and Finance, Volume 3, Number 1, 2004

Schifter, D.E. \& Ajzen, I. (1985). Intention, Perceived Control, and Weight Loss: An application of the Theory of Planned Behavior. Journal of Personality and Social Psychology, 49,3, 843-851.

Songer-Nocks, E. (1976). Situational Factors Affecting the Weighting of Predictor Components in the Fishbein Model. Journal of Experimental Social Psychology, 12, 56-69.

Straub, D., Limayem, M. \& Karahannan-Evaristo, E. (1995). Measuring System Usage: Implications for IS Theory Testing. Management Science, 41, 1328-42.

Taylor, S. \& Todd, P. (1995). Understanding Information Technology Usage: A test of competing models. Information Systems Research, 6,2, 144-176.

Teas, R.K. (1993). Expectations, Performance Evaluation and Consumer's Perceptions of Quality. Journal of Marketing,57, 18-34.

Venkatesh, V. (2000). Determinants of Perceived Ease of Use: Integrating Control, Intrinsic Motivation, and Emotion into the Technology Acceptance Model. Information Systems Research, 11, 342-365.

Williams, C. (1998). Is the SERVQUAL Model an Appropriate Management Tool for Measuring Service Delivery Quality in the UK Leisure Industry? Managing Leisure, 3, 98-110.

Zeithaml, V., Berry, L. \& Parasuraman, A. (1996). The Behavioural Consequences of Service Quality. Journal of Marketing, 60, 31-46.

Zeithaml, V.A. \& Bitner, M.J. (2000). Services Marketing: Integrating Customer Focus Across the Firm. New York, NY:McGraw-Hill. 
Table 1. Demographic and Rational Profile.

\begin{tabular}{|c|c|c|c|}
\hline Factors & Category & No of Respondents & Percent \\
\hline \multirow[t]{4}{*}{ Age } & $<25$ & 33 & 32.4 \\
\hline & $26-35$ & 31 & 30.4 \\
\hline & $36-45$ & 21 & 20.6 \\
\hline & $>46$ & 17 & 16.7 \\
\hline \multirow[t]{2}{*}{ Gender } & Male & 82 & 80.4 \\
\hline & Female & 20 & 19.6 \\
\hline \multirow{5}{*}{$\begin{array}{l}\text { Educational } \\
\text { Qualification }\end{array}$} & $<\mathrm{HSC}$ & 24 & 23.5 \\
\hline & UG & 26 & 25.5 \\
\hline & PG & 43 & 42.2 \\
\hline & Diploma & 7 & 6.9 \\
\hline & Others & 2 & 2.0 \\
\hline \multirow[t]{6}{*}{ Occupation } & Government & 29 & 28.4 \\
\hline & Private & 27 & 26.5 \\
\hline & Self Employed & 21 & 20.6 \\
\hline & Student & 7 & 6.9 \\
\hline & House Wife & 5 & 4.9 \\
\hline & Retired & 13 & 12.7 \\
\hline \multirow[t]{4}{*}{ Monthly Income } & $<10000$ & 42 & 41.2 \\
\hline & $10001-25000$ & 41 & 40.2 \\
\hline & $25001-40000$ & 13 & 12.7 \\
\hline & $>40000$ & 6 & 5.9 \\
\hline \multirow[t]{5}{*}{ No of dependent } & One & 5 & 4.9 \\
\hline & Two & 3 & 2.9 \\
\hline & Three & 36 & 35.3 \\
\hline & Four & 53 & 52.0 \\
\hline & Five and Above & 5 & 4.9 \\
\hline \multirow[t]{3}{*}{ Type of Account } & Saving & 82 & 80.4 \\
\hline & Salary & 8 & 7.8 \\
\hline & Current & 12 & 11.7 \\
\hline \multirow[t]{4}{*}{ Frequency of Visit to bank } & Everyday & 1 & 1.0 \\
\hline & 1-2 Times Per Week & 27 & 26.5 \\
\hline & 1-2 Times Per Fortnight & 32 & 31.4 \\
\hline & 1-2 Times Per Month & 42 & 41.2 \\
\hline \multirow[t]{2}{*}{ Marital Status } & Married & 56 & 54.9 \\
\hline & Unmarried & 46 & 45.1 \\
\hline
\end{tabular}

Table 2. Reliability Statistics of SERVQUAL construct.

\begin{tabular}{|l|l|}
\hline Cronbach's Alpha & N of Items \\
\hline .843 & 22 \\
\hline
\end{tabular}

Table 3. Reliability Statistics of Behavioral Intentions' construct.

\begin{tabular}{|l|l|}
\hline Cronbach's Alpha & No. of Items \\
\hline .706 & 13 \\
\hline
\end{tabular}


Table 4. Contribution of best set of service quality variables towards customers' attitudinal loyalty of public retail banks.

Dependent Variable: Attitudinal Loyalty.

\begin{tabular}{|l|l|l|l|l|l|}
\hline Independent Variables & $\begin{array}{l}\text { Unstandardized } \\
\text { Coefficients }\end{array}$ & $\begin{array}{l}\text { Standard } \\
\text { Error }\end{array}$ & $\begin{array}{l}\text { Standardized } \\
\text { Coefficients }\end{array}$ & t-ratio & Sig. \\
\hline (Constant) & -.085 & .609 & & -.140 & .889 \\
\hline Convenient operating hours (x1) & .359 & .084 & .424 & 4.269 & .000 \\
\hline Modern looking equipments (x2) & .282 & .118 & .204 & 2.396 & .019 \\
\hline Bank delivers error free records (x3) & .324 & .088 & .322 & 3.682 & .000 \\
\hline Employees give prompt service (x4) & -.206 & .064 & -.281 & -3.234 & .002 \\
\hline Visually appealing Service Materials (x5) & .205 & .067 & .245 & 3.066 & .003 \\
\hline Employees give customers personal attention (x6) & .251 & .081 & .295 & 3.117 & .002 \\
\hline Service right at the first time (x7) & -.192 & .086 & -.214 & -2.239 & .028 \\
\hline $\begin{array}{l}\text { Employees knowledge to answer customer questions } \\
\text { (x8) }\end{array}$ & -.191 & .074 & -.242 & -2.581 & .011 \\
\hline $\begin{array}{l}\text { Employees tell customers exactly when the service } \\
\text { will be performed (x9) }\end{array}$ & .169 & .085 & .185 & 1.996 & .049 \\
\hline
\end{tabular}

Multiple $\mathrm{R}=0.687$, F-Value $=9.126$, d.f $(9,92)$, $\mathrm{p}$-value $<0.01$, $\mathrm{R}$ Square $=0.472$

$\hat{\mathbf{Y}}=-0.085+0.359 \mathrm{x}_{1}+0.282 \mathrm{x}_{2}+0.324 \mathrm{x}_{3}-0.206 \mathrm{x}_{4}+0.205 \mathrm{x}_{5}+0.251 \mathrm{x}_{6}-0.192 \mathrm{x}_{7}-0.191 \mathrm{x}_{8}+0.169 \mathrm{x}_{9}$

Where $\hat{\mathbf{Y}}$ is the estimated attitudinal Loyalty

Table 5. Contribution of best set of service quality variables towards the customers' switching propensity of public retail banks

Dependent Variable: Switching Propensity

\begin{tabular}{|c|c|c|c|c|c|c|}
\hline \multirow[b]{2}{*}{ Model } & \multirow[b]{2}{*}{ Independent Variables } & \multicolumn{2}{|c|}{$\begin{array}{l}\text { Unstandardized } \\
\text { Coefficients }\end{array}$} & \multirow{2}{*}{$\begin{array}{l}\text { Standardized } \\
\text { Coefficients } \\
\text { Beta } \\
\end{array}$} & \multirow[b]{2}{*}{$\mathrm{t}$} & \multirow[b]{2}{*}{ Sig. } \\
\hline & & $\mathrm{B}$ & Std. Error & & & \\
\hline & (Constant) & .974 & .544 & & 1.790 & .077 \\
\hline & $\begin{array}{l}\text { REL P8 -Bank provides the service at the time it promise to do so } \\
\text { (x1) }\end{array}$ & .313 & .098 & .297 & 3.185 & .002 \\
\hline & $\begin{array}{l}\text { TAN P2 -Bank's physical facilities are visually appealing with } \\
\text { modern looking building and amenities (x } 2)\end{array}$ & .309 & .103 & .278 & 2.987 & .004 \\
\hline
\end{tabular}

Multiple $\mathrm{R}=0.386, \quad \mathrm{~F}$-Value $=8.666, \quad \operatorname{d.f}(2,99), \quad \mathrm{p}$-value $<0.01, \mathrm{R}$ Square $=0.149$

$\hat{\mathbf{Y}}=0.974+0.313 \mathrm{x}_{1}+0.309 \mathrm{x}_{2}$

Where $\hat{\mathbf{Y}}$ is the estimated Switching Propensity

Table 6. Contribution of best set of service quality variables towards customers' Pay More Sum intention of public retail banks

Dependent Variable: Pay More Sum

\begin{tabular}{|l|l|l|l|l|l|l|}
\hline $\begin{array}{l}\text { Mode } \\
1\end{array}$ & Independent Variables & \multicolumn{2}{|l|}{$\begin{array}{l}\text { Unstandardized } \\
\text { Coefficients }\end{array}$} & $\begin{array}{l}\text { Standardized } \\
\text { Coefficients }\end{array}$ & $\mathrm{t}$ & $\mathrm{t}$ \\
\hline & \multicolumn{1}{|l|}{ Sig. } \\
\hline & $\begin{array}{l}\text { B } \\
\text { (Constant) }\end{array}$ & .918 & .543 & & 1.689 & .094 \\
\hline & $\begin{array}{l}\text { TAN P2- Bank's physical facilities are visually appealing with } \\
\text { modern looking building and amenities (x1) }\end{array}$ & .443 & .118 & .326 & 3.760 & .000 \\
\hline $\begin{array}{l}\text { RES P10- Employees tell customers exactly when the service } \\
\text { will be performed (x2) }\end{array}$ & .362 & .111 & .292 & 3.249 & .002 \\
\hline $\begin{array}{l}\text { ASSU P17 -Employees have the knowledge to answer } \\
\text { customer questions (x3) }\end{array}$ & -.338 & .101 & -.317 & -3.335 & .001 \\
\hline & EMP P19 -Convenient operating hours to all its customers (x4) & .313 & .114 & .272 & 2.742 & .007 \\
\hline
\end{tabular}

Multiple $\mathrm{R}=0.593$, F-Value $=13.136$, d.f $(4,97)$, $\mathrm{p}$-value $<0.01$, R Square $\mathrm{e}=0.351$

$\hat{\mathbf{Y}}=0.918+0.443 \mathrm{x}_{1}+0.362 \mathrm{x}_{2}-0.338 \mathrm{x}_{3}+0.313 \mathrm{x}_{4}$

Where, $\hat{\mathbf{Y}}$ is the estimated Pay More Sum. 
Table 7. Contribution of best set of service quality variables towards customers' External and Internal response intention

Coefficients (a)

Dependent Variable: External and Internal Response.

\begin{tabular}{|c|c|c|c|c|c|c|}
\hline \multirow[t]{2}{*}{ Model } & \multirow[t]{2}{*}{ Independent Variables } & \multicolumn{2}{|c|}{$\begin{array}{l}\text { Unstandardized } \\
\text { Coefficients }\end{array}$} & \multirow{2}{*}{$\begin{array}{l}\text { Standardized } \\
\text { Coefficients } \\
\text { Beta }\end{array}$} & \multirow[t]{2}{*}{$\mathrm{t}$} & \multirow[t]{2}{*}{ Sig. } \\
\hline & & $\mathrm{B}$ & Std. Error & & & \\
\hline & (Constant) & 2.739 & 2.209 & & 1.240 & .218 \\
\hline & TAN P1-Modern looking equipments (x1) & 1.512 & .382 & .329 & 3.962 & .000 \\
\hline & $\begin{array}{l}\text { EMP P22- Employees understands customers specific } \\
\text { needs (x2) }\end{array}$ & 1.008 & .308 & .324 & 3.271 & .001 \\
\hline & $\begin{array}{l}\text { REL- P5 Banks promises to do something by a certain } \\
\text { time, it does so }(\mathrm{x} 3)\end{array}$ & .764 & .245 & .268 & 3.117 & .002 \\
\hline & $\begin{array}{l}\text { EMP P20 - Employees give customers personal } \\
\text { attention }(\mathrm{x} 4)\end{array}$ & -.784 & .270 & -.278 & -2.904 & .005 \\
\hline & $\begin{array}{l}\text { ASSU P14 -The behavior of employees insist confidence } \\
\text { to customers (x5) }\end{array}$ & .508 & .227 & .202 & 2.241 & .027 \\
\hline & TAN P3- Neat appearing frontline employees (x6) & .442 & .220 & .170 & 2.011 & .047 \\
\hline
\end{tabular}

Multiple $\mathrm{R}=0.609$, F-Value $=9.355$, d.f $(6,95)$, $\mathrm{p}$-value $<0.01$, R Square $=0.371$

$\hat{\mathbf{Y}}=2.739+1.512 \mathrm{x}_{1}+1.008 \mathrm{x}_{2}+0.764 \mathrm{x}_{3}-0.784 \mathrm{x}_{4}+0.508 \mathrm{x}_{5}+0.442 \mathrm{x}_{6}$

Where $\hat{\mathbf{Y}}$ is the estimated External and Internal Response

Table 8. Contribution of best set of service quality variables towards customers' Overall Behavior Intention

\begin{tabular}{|c|c|c|c|c|c|c|}
\hline \multirow[t]{2}{*}{ Model } & \multirow[t]{2}{*}{ Independent Variables } & \multicolumn{2}{|c|}{$\begin{array}{l}\text { Unstandardized } \\
\text { Coefficients }\end{array}$} & \multirow{2}{*}{$\begin{array}{l}\text { Standardized } \\
\text { Coefficients } \\
\text { Beta } \\
\end{array}$} & \multirow[t]{2}{*}{$\mathrm{t}$} & \multirow[t]{2}{*}{ Sig. } \\
\hline & & $\mathrm{B}$ & Std. Error & & & \\
\hline \multirow{6}{*}{5} & (Constant) & .609 & .410 & & 1.485 & .141 \\
\hline & EMP- Convenient operating hours (x1) & .135 & .052 & .241 & 2.611 & .010 \\
\hline & TAN P1- Modern looking equipment (x2) & .288 & .075 & .316 & 3.868 & .000 \\
\hline & EMP P22- The employee understands customers specific need (x3) & .170 & .052 & .275 & 3.244 & .002 \\
\hline & $\begin{array}{l}\text { TAN P2 -Bank's physical facilities are visually appealing with } \\
\text { modern looking building and amenities }(\mathrm{x} 4)\end{array}$ & .147 & .056 & .222 & 2.618 & .010 \\
\hline & TAN P3- Bank's frontline employees are neat appearing (x5) & .100 & .044 & .194 & 2.303 & .023 \\
\hline
\end{tabular}

Dependent Variable: Overall Behavioral Intention

Multiple $\mathrm{R}=0.665$, F-Value $=15.263$, d.f $(5,96)$, $\mathrm{p}$-value $<0.01$, R Square $=0.443$

$\hat{\mathbf{Y}}=0.609+0.135 \mathrm{x}_{1}+0.288 \mathrm{x}_{2}+0.170 \mathrm{x}_{3}+0.147 \mathrm{x}_{4}+0.100 \mathrm{x}_{5}$

Where, $\hat{Y}$ is the estimated Overall Behavioral Intention.

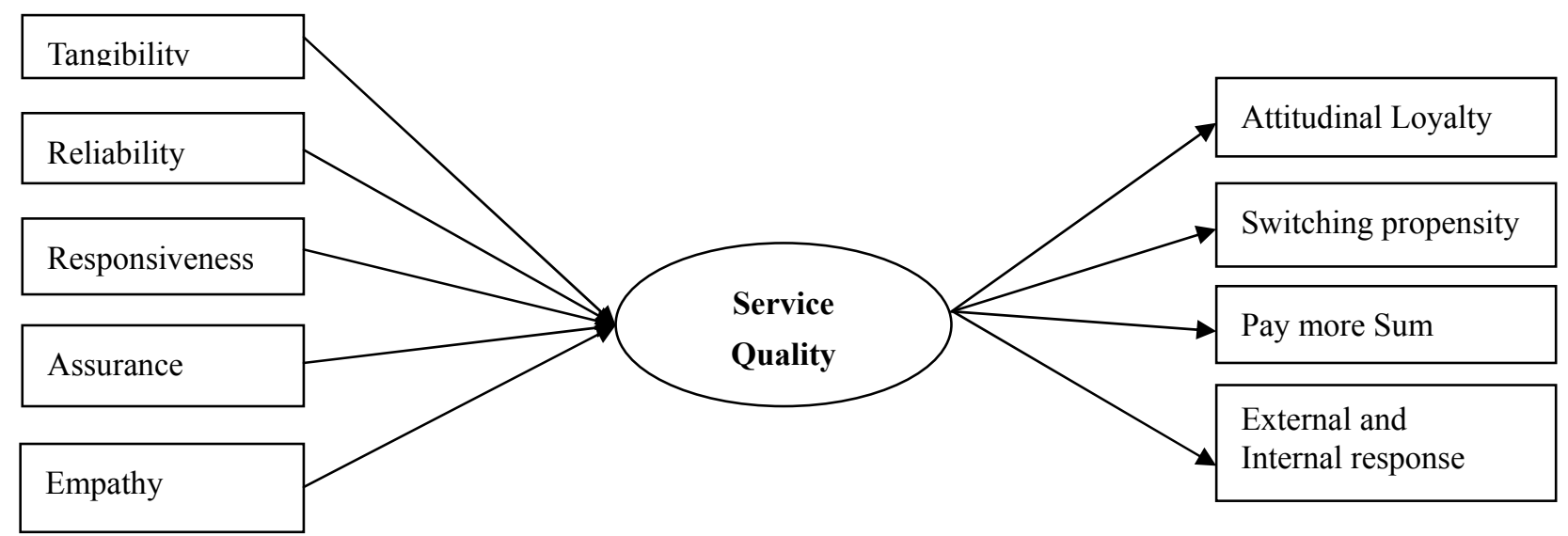

Figure1. Proposed Model for this study 